\title{
Is the High Court Mistaken about the Aim of Statutory Interpretation?
}

\section{Dale Smith*}

In recent years, the High Court has expressed scepticism about legislative intent. It has denied that the aim of statutory interpretation is to discover the intentions Parliament conveyed through its use of the words contained in the statute, at least if we understand those intentions as some sort of 'objective collective mental state'. ${ }^{1}$ Legislative intent in this sense, says the Court, is fictitious or metaphorical; the phrase 'legislative intent' should be understood as merely a label attached to a meaning that is identified (or perhaps constructed) by applying widely accepted principles of statutory interpretation.

The High Court's scepticism about legislative intent has attracted a great deal of attention, from both supporters and critics. ${ }^{2}$ However, the High Court has a more fundamental commitment with regard to statutory interpretation, one that has received far less scrutiny. This commitment arises out of the Court's claim that the ultimate aim when interpreting a statutory provision is to ascertain the meaning of the words contained in the provision. One way of viewing the controversy about legislative intent is that it is about what determines the meaning of those words. Is their meaning constituted by Parliament's intentions (to convey certain information via the use of those words), or is it instead fixed by the application of widely accepted principles of statutory interpretation? Viewed in this way, the debate about legislative intent takes place within a framework that has already been

\footnotetext{
* Melbourne Law School, University of Melbourne. I am grateful to participants at a seminar at Melbourne Law School at which an earlier version of this article was presented. I am also grateful to Hrafn Asgeirsson, Patrick Emerton, Jeff Goldsworthy, Larry Solum and David Tan for very helpful comments on an earlier draft, and to an anonymous referee for their helpful suggestions. This research was supported under the Australian Research Council's Discovery Projects funding scheme (project number DP140102670).

${ }^{1}$ Lacey v Attorney-General (Qld) (2011) 242 CLR 573 ('Lacey'), 592 (French CJ, Gummow, Hayne, Crennan, Kiefel and Bell JJ). Some would deny that the Court's scepticism about legislative intent is all that recent, pointing (for example) to the wording of the famous passage from Project Blue Sky: 'the duty of a court is to give the words of a statutory provision the meaning that the legislature is taken to have intended them to have.' (Project Blue Sky Inc v Australian Broadcasting Authority (1998) 194 CLR 355 ('Project Blue Sky'), 384 (McHugh, Gummow, Kirby and Hayne JJ) (emphasis added).)

${ }^{2}$ See, eg, Richard Ekins and Jeffrey Goldsworthy, 'The Reality and Indispensability of Legislative Intentions' (2014) 36 Sydney Law Review 39 (who are highly critical of the High Court's scepticism) and Joseph Campbell and Richard Campbell, 'Why Statutory Interpretation is Done as it is Done' (2014) 39 Australian Bar Review 1 (who are broadly sympathetic to the High Court's position).
} 
structured by a commitment to ascertaining the meaning of the words contained in the statute. ${ }^{3}$

My goal in this article is to challenge the High Court's claim that the ultimate aim of statutory interpretation is to ascertain the meaning of the words contained in the provision being interpreted. I shall call this claim 'the meaning thesis', and I shall argue that it cannot account for important features of the practice of statutory interpretation. In particular, it can account for only some of the ways in which statutory provisions interact with other legal norms (including other statutory provisions). I shall contend that this provides a powerful reason to reject the meaning thesis. ${ }^{4}$

Of course, ascertaining the meaning of the words contained in the provision being interpreted is an important step in the interpretive process. However, I shall argue, the High Court is wrong to claim that it represents the ultimate aim of statutory interpretation. This gives rise to an obvious objection, even before I give my reasons for rejecting the meaning thesis - namely, that it is not possible for the High Court to be mistaken about such a fundamental aspect of Australian law. In Section 1, I seek to show that this objection is misguided and, in doing so, to clarify the argumentative strategy I shall employ in the article.

In Section 2, I show that the High Court does indeed endorse the meaning thesis, and I suggest some reasons why that thesis may appear attractive. Then, in Section 3, I present an initial objection to the Court's position. I argue that, given its scepticism about legislative intent, the High Court cannot account for some uncontroversial features of statutory interpretation - such as the presumption of mens rea that is employed when interpreting criminal offence provisions - consistently with the meaning thesis. Moreover, even if the Court were to abandon its scepticism about legislative intent, its acceptance of the meaning thesis would still leave it struggling to account for the presumption of mens rea.

\footnotetext{
${ }^{3}$ I do not mean to imply that someone who is not sceptical about legislative intent must regard it as contributing to the meaning of the words in the statute. This is, perhaps, the standard approach (see, eg, Ekins and Goldsworthy, above n 2), but one might believe that legislative intent is relevant independent of any contribution it makes to the meaning of the words in the statute.

${ }^{4}$ I believe that many academic commentators also accept the meaning thesis, though I shall not seek to substantiate that claim in this article. If I am right, the difficulties for the meaning thesis that I identify pose problems, not only for the High Court, but for much academic writing about statutory interpretation as well.
} 
In Section 4, I suggest that there are other aspects of the practice of statutory interpretation that it is even more difficult for the High Court to explain, given its acceptance of the meaning thesis. Here, I focus particularly on principles of statutory interpretation such as s 15AA of the Acts Interpretation Act 1901 (Cth) - that apply to statutes that were enacted before those principles were introduced into the law. In Section 5, I consider three ways in which the High Court might seek to show that the operation of these principles is consistent with the meaning thesis. I argue that none of these is promising. I conclude, in Section 6, by briefly suggesting how we might begin developing a more satisfactory account of the aim of statutory interpretation.

\section{Can the High Court Be Mistaken about the Aim of Statutory Interpretation?}

Before I seek to show that the High Court is mistaken about the ultimate aim of statutory interpretation, I must address a preliminary objection - namely, that it is not possible for the High Court to be mistaken about such a fundamental aspect of Australian law. There is both a crude and a more subtle version of this objection. The crude version asserts that the law in Australia is whatever the High Court says it is, since the Court has the final say on what the law is. On this view, if the High Court says that the ultimate aim of statutory interpretation is to identify the meaning of the words contained in the statute, then that is the ultimate aim of statutory interpretation. One might contend that the Court should have adopted a different approach, but one cannot plausibly claim that the Court is mistaken about what the legal position is.

Hopefully, the claim that the High Court cannot be mistaken about what the law is in Australia strikes the reader as implausible. As HLA Hart pointed out more than fifty years ago, claims of this sort confuse finality with infallibility. ${ }^{5}$ That the High Court has the final say on what the law is means that any errors of law made by the Court cannot easily be corrected. However, it does not mean that the Court is infallible about what the law is - it may still get the law wrong, even if there is no legal avenue to appeal its mistakes. ${ }^{6}$ And to claim that the law is whatever the High Court says it is leaves one unable to explain what the

\footnotetext{
${ }^{5}$ HLA Hart, The Concept of Law (Clarendon Press, $3^{\text {rd }}$ ed, 2012) 141-6.

${ }^{6}$ Though, where the mistake occurs in the course of interpreting a statute, it is open to Parliament to amend the statute.
} 
Court is doing when it seeks to ascertain what the law is, since it follows from that claim that whatever the Court decides will be (legally) correct. ${ }^{7}$

There is, however, a more subtle version of the objection. On this view, while the High Court can be mistaken about what the law is, the doctrine of precedent means that those mistakes may play a role in determining what the law is subsequent to the Court's decision. What role those mistakes play varies depending on the circumstances. In particular, the law may not always immediately alter to fit the Court's decision (eg if that decision conflicts with other High Court decisions). Nevertheless, those mistakes may play a role, raising the possibility that, even if the Court was mistaken when it first stated that the aim of statutory interpretation is to identify the meaning of the words contained in the statute, this misunderstanding subsequently shaped the law in Australia, so that it now reflects the correct legal position.

This is a genuine possibility, and one I will not be in a position to reject until I explain why the meaning thesis is mistaken. However, I should indicate what my argumentative strategy will be. I shall seek to show that the High Court's characterisation of the aim of statutory interpretation (as seeking to identify the meaning of the words contained in the statute) conflicts with numerous, more concrete aspects of the practice of statutory interpretation. Put bluntly, what the High Court says it is doing when it interprets statutes conflicts with what it actually does. Moreover, we should privilege what the Court does over what it says it is doing, not least because its statements about the ultimate aim of statutory interpretation are attempts to identify the role that the more specific principles play in the interpretive process. If, as I shall argue, those statements fail in this attempt, then we have reason to call them into question. (It might be objected that the High Court's statements about the ultimate aim of statutory interpretation trump any inconsistent principles of statutory interpretation because they reflect a constitutional imperative - namely, that, when interpreting statutes, judicial power is limited to ascertaining the meaning of the words contained in the statute. I consider this objection in Section 5A.)

\section{The Meaning Thesis}

\footnotetext{
${ }^{7}$ Hart, above n 5, 146-7.
} 
The previous Section sought to establish only that it is possible that the High Court is mistaken about the aim of statutory interpretation. Before I seek to show that the meaning thesis is mistaken, we should examine that thesis in more detail.

\title{
A. High Court jurisprudence
}

In Project Blue Sky, McHugh, Gummow, Kirby and Hayne JJ stated that:

\begin{abstract}
[T] he duty of a court is to give the words of a statutory provision the meaning that the legislature is taken to have intended them to have. Ordinarily, that meaning (the legal meaning) will correspond with the grammatical meaning of the provision. But not always. The context of the words, the consequences of a literal or grammatical construction, the purpose of the statute or the canons of construction may require the words of a legislative provision to be read in a way that does not correspond with the literal or grammatical meaning. ${ }^{8}$
\end{abstract}

There is much to be gleaned from this passage, but the most important point is that, according to the joint judgment, the aim when interpreting a statutory provision is to identify the 'legal meaning' of the words in the provision - that is, the meaning that Parliament is taken to have intended the words to have.

The joint judgment distinguished between the 'legal meaning' of the words and their literal or grammatical meaning. Whilst indicating that the two will commonly correspond, their Honours identified several factors (context, purpose, etc) that might cause the legal meaning of the words to depart from their literal or grammatical meaning. In doing so, their Honours recognised that there is more than one type of meaning that words can be said to bear, both in ordinary conversation and in legal contexts. Consider a doctor who says to her patient, 'You are not going to die.'9 The literal meaning of the statement is, arguably, that the patient is immortal. However, the doctor most likely means to communicate, not that the patient will never die, but rather that he will not die from the particular illness or complaint that led him to see her on this occasion.

\footnotetext{
${ }^{8}$ Project Blue Sky (1998) 194 CLR 355, 384 (footnote omitted).

${ }^{9}$ This example comes from Scott Soames, 'Interpreting Legal Texts: What Is, and What Is Not, Special about the Law' in Philosophical Essays, Volume 1: Natural Language - What It Means and How We Use It (Princeton University Press, 2010) 410. It is a variation on an example offered by Kent Bach: Kent Bach, 'Conversational Impliciture' (1994) 9 Mind and Language 124, 134.
} 
Philosophers of language distinguish between semantics and pragmatics. Semantics involves the study of the properties of types of expression (eg the properties that a sentence has independent of any particular context in which it is uttered), whereas pragmatics involves the study of properties specific to the utterance of a particular type of expression on a particular occasion (eg the distinctive properties that a sentence has when uttered in a certain context). ${ }^{10}$ So the conclusion that the doctor in our example is not asserting that her patient is immortal is based on pragmatic considerations (in particular, the contextual factor that she is responding to an inquiry about a particular illness or complaint), considerations that go beyond the semantic properties of the sentence 'You are not going to die.'

It is tempting to think of semantics as providing what the High Court calls the literal or grammatical meaning of a statutory provision, while what it calls the 'legal meaning' incorporates pragmatic considerations generated by the context in which the words in the provision are used. ${ }^{11}$ If so, we can interpret the High Court as saying that, while the legal meaning of a statutory provision will often correspond to its semantic content, we also need to take into account pragmatic considerations (context, purpose, etc) that may cause the provision's legal meaning to depart from its semantic content. ${ }^{12}$

The distinction between semantic and pragmatic content will play an important role in the argument later in this article. However, for the moment, the crucial point is not that the High Court distinguishes between legal meaning and literal or grammatical meaning, or that this can plausibly be regarded as mapping onto the distinction between semantic and

\footnotetext{
${ }^{10}$ Kepa Korta and John Perry, 'Pragmatics' in Edward N Zalta (ed), The Stanford Encyclopedia of Philosophy (Winter 2012 Edition) <http://plato.stanford.edu/archives/win2012/entries/pragmatics/>. This way of distinguishing between semantics and pragmatics is controversial, but we need not be too concerned with this controversy. Whatever the precise nature of the distinction, it appears closely related to the distinction that the High Court draws between legal meaning and literal or grammatical meaning.

${ }^{11}$ The joint judgment in Project Blue Sky explicitly referred to context as one factor that may cause legal meaning to diverge from literal or grammatical meaning, and the High Court has recently reiterated that context is relevant only in so far as it helps identify the meaning of the text (Federal Commissioner of Taxation $v$ Consolidated Media Holdings Ltd (2012) 250 CLR 503, 519 ('Consolidated Media')). Other factors mentioned in Project Blue Sky, such as purpose, can plausibly be regarded as part of the context: see, eg, Thiess $v$ Collector of Customs (2014) 250 CLR 664, 672 ('Thiess') (treating the identification of statutory purpose as part of 'contextual construction').

${ }^{12}$ I point out below that standard accounts of pragmatics point to the speaker's intentions to explain how pragmatic content is generated. Since the High Court is sceptical about legislative intent (in any sense that could generate pragmatic content), it might seem mistaken to ascribe to the Court the view that we must take into account pragmatic considerations when ascertaining the legal meaning of a statute. However, it is not clear how else we are to understand the Court's distinction between legal meaning and literal or grammatical meaning. In what other way could legal meaning extend beyond literal or grammatical meaning, consistent with the Court's clear indication that legal meaning is concerned with the meaning of the words in the statute?
} 
pragmatic content. Rather, the crucial point is that, according to the High Court, the role of a judge when interpreting a statutory provision is to ascertain the meaning - or, as I shall refer to it from now on, the 'linguistic content' - of that provision. ${ }^{13}$ (As I use the phrase, 'linguistic content' may encompass both semantic and pragmatic content.)

It is not only Project Blue Sky that supports my claim that the High Court accepts the meaning thesis. Recently, in a unanimous judgment, the Court stated that '[s]tatutory construction involves attribution of meaning to statutory text. ${ }^{14}$ Admittedly, references to 'meaning' can be ambiguous - they may be references either to linguistic content or to the significance of a particular event or state of affairs (as when we inquire as to the meaning of a recent political development). ${ }^{15}$ However, it is tolerably clear that the Court has in mind meaning in the former sense. The Court goes on to emphasise that " "[u]nderstanding context has utility if, and in so far as, it assists in fixing the meaning of the statutory text.", ${ }^{16}$ An appreciation of the context is obviously crucial to understanding the significance of an event or state of affairs; emphasising the limits of the use of context makes more sense if one's goal is to ascertain the linguistic content of certain words. ${ }^{17}$

Thus, the High Court views the role of a judge, when interpreting a statutory provision, as being to ascertain the linguistic content of that provision. Presumably, the Court also regards the role of a judge as being to identify the provision's legal effect - that is, the contribution that the provision makes to the content of the law. ${ }^{18}$ Thus, we can ascribe to the Court the view that a provision's legal effect is equivalent to its linguistic content. ${ }^{19}$

\footnotetext{
${ }^{13}$ I use the phrase 'linguistic content', rather than the word 'meaning', because - as we shall see - the latter is ambiguous.

${ }^{14}$ Thiess (2014) 250 CLR 664, 671. I take it that the Court uses the terms 'construction' and 'interpretation' interchangeably, and I shall follow it in this regard. Cf Lawrence B Solum, 'The Interpretation-Construction Distinction’ (2010) 27 Constitutional Commentary 95.

${ }^{15}$ Mark Greenberg, 'The Standard Picture and Its Discontents' in Leslie Green and Brian Leiter (eds), Oxford Studies in Philosophy of Law: Vol. 1 (Oxford University Press, 2011) 48.

${ }^{16}$ Thiess (2014) 250 CLR 664, 671 (quoting from Consolidated Media (2012) 250 CLR 503, 519).

${ }^{17}$ We have also seen that the joint judgment in Project Blue Sky stated that a provision's legal meaning often corresponds to its literal or grammatical meaning. This is plausible if 'legal meaning' refers to linguistic content, but it is far more contentious to suggest that the significance of a statutory provision often corresponds to its literal or grammatical meaning.

${ }^{18}$ Greenberg claims that we should understand this contribution in terms of the relevant difference that the provision makes to people's legal rights, obligations, powers, etc: Mark Greenberg, 'Legislation as Communication? Legal Interpretation and the Study of Linguistic Communication' in Andrei Marmor and Scott Soames (eds), Philosophical Foundations of Language in the Law (Oxford University Press, 2011) 222.

${ }^{19}$ This is a thesis about the legal effect of valid provisions, and so it is no objection to the thesis that the legal effect of a repealed or constitutionally invalid provision departs from its linguistic content (because the provision has no legal effect, despite having linguistic content).
} 
According to the Court, judges should ascertain the provision's legal effect by ascertaining its linguistic content. Moreover, it is unlikely that the Court thinks that this is so because the legal effect of statutory provisions just happens to fortuitously coincide with their linguistic content. ${ }^{20}$ Rather, the more plausible reading is that the Court believes that a provision's linguistic content determines its legal effect, in the sense that the contribution that the provision makes to the content of the law is a function of the meaning of the words contained in the provision. This explains why the Court claims that the ultimate aim of statutory interpretation is to ascertain the meaning of those words.

It is worth pausing to note that the High Court fails to draw clearly the distinction between legal effect and linguistic content. ${ }^{21}$ As a result, much of what the Court says about statutory interpretation might be thought to be ambiguous, on the basis that it is unclear whether the Court is talking about linguistic content, legal effect or both. However, the Court's failure to draw the distinction is further evidence that it embraces the meaning thesis. If one believes that a provision's legal effect is equivalent to its linguistic content, then one may not be particularly concerned to distinguish between them.

There is, however, an important objection to my interpretation of the High Court's position. ${ }^{22}$ I have ascribed to the Court the view that the aim of statutory interpretation is to ascertain the linguistic content of the provision being interpreted. On this view, linguistic content is something to be found, not constructed. However, the Court often talks in terms of 'giving' or 'attributing' meaning to a provision. ${ }^{23}$ This might be taken to suggest that the Court does not believe that the aim of statutory interpretation is to ascertain the provision's linguistic content, but rather to construct a meaning which is then attributed to the provision.

When the Court speaks of 'giving' or 'attributing' meaning to a provision, it has in mind the application of principles of statutory interpretation. However, I doubt that the Court believes that the application of these principles constitutes - as opposed to helping to identify - the meaning of the words in the provision. This would suggest that the words have no meaning until the principles are applied. Not only would this result in a sharp distinction

\footnotetext{
${ }^{20}$ Indeed, the Court may believe that the correspondence between legal effect and linguistic content is constitutionally mandated: see below $\mathrm{n} 71$.

${ }^{21}$ The same is true of many academic commentators. Notable exceptions include Greenberg, above n 15, 47-9; Lawrence B Solum, 'Communicative Content and Legal Content' (2013) 89 Notre Dame Law Review 479, 479.

${ }^{22}$ I am grateful to Jeff Goldsworthy for drawing my attention to this objection.

${ }^{23}$ See, eg, the text for above nn 8 and 14.
} 
between legal discourse and ordinary conversation (where the meaning of utterances is not constructed in this way), it would also mean that the statute could not guide people's behaviour until its meaning was constructed by a court. ${ }^{24}$ (To the extent that they were concerned with acting lawfully, people would have to base their behaviour on guesses as to what meaning would be constructed by the court.) Thus, it is more plausible to ascribe to the High Court the view that the aim of statutory interpretation is to ascertain the linguistic content of the provision being interpreted, rather than the view that statutory interpretation involves constructing a meaning that did not previously exist. ${ }^{25}$

A further reason to interpret the Court in this way derives from the statement in Project Blue Sky that a provision's legal meaning will usually correspond to its literal or grammatical meaning. If legal meaning is 'constructed', why think that it will generally correspond to the literal or grammatical meaning of the words in the provision, unless this process of 'construction' is really a process of ascertaining what the linguistic content of the words is?

An alternative objection to my interpretation of the High Court's position is that the meaning thesis can be ascribed to particular judges, but not to the Court as a whole. Just as there is debate about what, if any, intentions can be ascribed to the legislature as a whole, there is room for debate about how (or whether) we should ascribe views about statutory interpretation to the High Court as a whole. ${ }^{26}$ Nevertheless, the core tenets of the meaning thesis are set out in Project Blue Sky, which is the leading High Court decision on statutory interpretation. Those tenets have since been endorsed in unanimous High Court decisions, such as Thiess. Given this, we are warranted in ascribing the meaning thesis, not just to particular judges, but to the High Court as a whole.

\section{B. The appeal of the meaning thesis}

\footnotetext{
24 Jeff Goldsworthy makes a similar point in critiquing what he calls extreme 'realist' theories of legal interpretation: Jeffrey Goldsworthy, Parliamentary Sovereignty: Contemporary Debates (Cambridge University Press, 2010) 230. Indeed, he suggests that, if such a theory were correct, a statute would not be law until its meaning was constructed by a court.

${ }^{25}$ This is not to deny that courts sometimes have to make new law to fill gaps in a statute (see Section 2B), but it is to ascribe to the High Court the view that such cases are the exception, not the rule.

${ }^{26}$ Especially as not every remark by a High Court judge fits easily with the meaning thesis: see below n 43 .
} 
Why is the High Court attracted to the meaning thesis? My answer to this question will be somewhat speculative, since the Court has said relatively little about why it regards the aim of statutory interpretation as being to ascertain the linguistic content of the provision being interpreted. Nevertheless, there are hints in the case law, and in the academic literature, as to why the meaning thesis might be thought to be attractive, and it is worth pursuing those hints to obtain a better appreciation of the strengths of that thesis.

Firstly, the meaning of the words contained in a statute obviously plays an important role in fixing the statute's legal effect. As a general rule, if the statute contained different words, it would have a different legal effect. There might be thought to be an obvious reason for this: a statute consists of words on a page, and so its legal effect must match the meaning of those words. Alternatively, the enactment of a statute might be thought to involve an act of communication by the legislature to the law's subjects (or some sub-set thereof), and this might be thought to entail that the statute's legal effect is equivalent to what is communicated (ie its linguistic content). ${ }^{27}$ Either way, the meaning thesis may appear to be vindicated.

Secondly, the meaning thesis appears to place principled restraints on judicial power. According to that thesis, a judge's role when interpreting a statute is to ascertain the meaning of the words contained in the statute, as opposed to drawing on her own moral beliefs or her speculations about the political motives behind the words. This attributes to judges a circumscribed role, one that does not require them to engage in controversial moral or political reasoning when interpreting statutes. Limiting the role of judges in this way might be thought to promote both democracy and the rule of law.

Thirdly, and relatedly, the meaning thesis appears to respect the separation of judicial and legislative power under the Commonwealth Constitution, since it allows for clearly defined roles to be assigned to both the legislature and the judiciary. ${ }^{28}$ Put crudely, the role of the legislature is to enact legislation; the role of the judiciary is to ascertain the meaning of the words contained in that legislation. (The High Court may believe that the meaning thesis

\footnotetext{
${ }^{27}$ It is unclear whether this line of thought has influenced the High Court, but it has clearly influenced some academic commentators: see, eg, Goldsworthy, above n 24, 263-4.

${ }^{28}$ The conjecture that the High Court's approach to statutory interpretation is influenced by such considerations finds support in the Court's repeated references to the constitutional dimension of statutory interpretation: see, eg, Zheng v Cai (2009) 239 CLR 446, 455-6. (While there is not a strict separation of judicial and legislative power at the State level, the Kable doctrine requires that relatively discrete roles be assigned to the legislature and the courts: Kable v DPP (NSW) (1996) 189 CLR 51.)
} 
is correct, not because it allows for clearly defined roles to be assigned to the legislature and judiciary, but because it identifies the roles that have in fact been assigned to these branches of government by the Constitution. I consider whether that belief is sound in Section 5A.)

Admittedly, this picture of the judicial role needs to be qualified, since the meaning of the words in a statute will not supply an answer to every legal question pertaining to that statute. It follows from the meaning thesis that, where the statute's linguistic content does not provide an answer, the law has run out, and so the court needs to make new law to fill the gap in the law. In making new law, judges may need to appeal to their own moral or political views, or to their views about the moral and political judgments that Parliament would have made had it considered the issue in question. ${ }^{29}$ Nevertheless, the meaning thesis remains attractive, because it suggests that - in those cases where the statute does provide an answer the role of the judge is both circumscribed and clearly demarcated from that of the legislature.

\section{The Presumption of Mens Rea}

In Section 2, I argued that the High Court accepts the meaning thesis, and considered some of the reasons why that thesis may appear to be attractive. Nevertheless, the meaning thesis should be rejected. For one thing, it struggles to account for some uncontroversial features of statutory interpretation. To show this, I begin with one of several counter-examples that Mark Greenberg has offered to views like the meaning thesis. ${ }^{30}$

In common law jurisdictions in Australia, there is a presumption that a criminal offence created by statute has a subjective fault element, even if there is no reference in the statute to a fault element. ${ }^{31}$ It seems, therefore, that the legal effect of a statutory provision that creates a criminal offence often differs from its linguistic content. Where the presumption is not rebutted, the legal effect of the provision is (among other things) to require that the prosecution establish a subjective fault element on the part of the defendant. (I shall refer to this as 'a mens rea requirement'.) However, if there is no reference in the

\footnotetext{
${ }^{29}$ For discussion of how judges should fill gaps in the law, see, eg, Hart, above n 5, 273; Peter Cane, 'Taking Disagreement Seriously: Courts, Legislatures and the Reform of Tort Law' (2005) 25 Oxford Journal of Legal Studies 393, 409-10.

${ }^{30}$ Greenberg, above n 15, 76. I have adapted this example to the Australian context. It should also be noted that Greenberg's target is what he calls 'the Standard Picture'; he regards what I am calling the meaning thesis as a corollary of the Standard Picture (at 47-9).

${ }^{31}$ He Kaw Teh v R (1985) 157 CLR 523.
} 
provision to a mens rea requirement, that requirement may not be part of the provision's linguistic content. If so, we cannot say that the aim when interpreting this provision is simply to ascertain its linguistic content, since this would be to overlook the role played by the presumption of mens rea.

The meaning thesis is not so easily defeated, however. If we equate the provision's linguistic content with its literal or grammatical meaning, then the presumption of mens rea represents a clear counter-example to the meaning thesis. Where a provision makes no reference to a mens rea requirement, that requirement cannot form part of its literal meaning. However, we have seen that the High Court denies that a provision's linguistic content always corresponds to its literal meaning. Once we allow that a provision's linguistic content extends to its pragmatic content, it may be possible to account for the presumption of mens rea consistently with the meaning thesis.

This depends, however, on which account of linguistic content one accepts. Understandably, the High Court does not offer a well-developed account of linguistic content. It claims that a provision's linguistic content may depart from the literal meaning of the words in question, because of the context, statutory purpose or - of particular relevance here - canons of construction. However, it does not explain how a canon of construction such as the presumption of mens rea may contribute to a provision's linguistic content.

Nevertheless, there are accounts which appear to support the view that canons of construction such as the presumption of mens rea may contribute to the linguistic content of statutory provisions. Consider, for example, the account offered by Richard Ekins and Jeff Goldsworthy (which, following Greenberg, I shall refer to as 'the objective communication theory'). ${ }^{32}$ According to Ekins and Goldsworthy, a provision's linguistic content consists of the information that we have reasonable grounds, based on the publicly available evidence, to regard Parliament as intending to convey via its use of the words in the provision. ${ }^{33}$ The presumption of mens rea, it could be argued, gives us reason to believe that Parliament intends to convey that a criminal offence created by statute contains a mens rea requirement,

\footnotetext{
${ }^{32}$ Greenberg, above n 18, 231. A similar account is offered by philosophers of language such as Scott Soames (Scott Soames, 'What Vagueness and Inconsistency Tell Us about Interpretation', in Marmor and Soames, above n 18) and legal philosophers such as Andrei Marmor (Andrei Marmor, The Language of Law (Oxford University Press, 2014) 19).

${ }^{33}$ Ekins and Goldsworthy, above n 2, 51.
} 
even though the provision does not expressly refer to that requirement. ${ }^{34}$ If so, then it follows from the objective communication theory that the mens rea requirement forms part of the linguistic content of the provision, and so the provision's legal effect is equivalent to its linguistic content. ${ }^{35}$

However, this way of accounting for the mens rea example requires us to ascribe intentions to Parliament - intentions which fix the linguistic content (and hence, according to the meaning thesis, the legal effect) of statutory provisions. As already mentioned, in cases such as Lacey, ${ }^{36}$ the High Court has denied that legislative intentions of this sort exist. This means that the Court cannot appeal to the objective communication theory to account for the mens rea example. ${ }^{37}$

The objective communication theory is not the only account of linguistic content. However, other mainstream theories also generate pragmatic content out of the mental states (usually intentions) of the speaker. ${ }^{38}$ In the statutory context, this appears to require that one accept some account of legislative intent. If so, the High Court's scepticism about legislative intent precludes it from using any of these theories to account for the mens rea example. ${ }^{39}$

Philosophers of language sometimes talk of pragmatic content as being generated from a common background shared by the speaker and audience. Typically, this is intended

\footnotetext{
${ }^{34}$ Though this reason is defeasible (ie the presumption is rebuttable), depending on the wording of the provision, the utility of imposing strict liability, etc: He Kaw Teh v R (1985) 157 CLR 523, 529-30 (Gibbs CJ).

${ }^{35}$ This is, very roughly, how Ekins and Goldsworthy seek to account for the presumption of mens rea. They suggest that a mens rea requirement is presupposed by Parliament when it enacts criminal statutes, in a way that contributes to the linguistic content of those statutes, and they seek to account for presuppositions of this sort in terms of the speaker's (in this case, Parliament's) intentions: Ekins and Goldsworthy, above n 2, 56-7.

${ }^{36}$ (2011) 242 CLR 573.

${ }^{37}$ Ekins and Goldsworthy make a similar point: Ekins and Goldsworthy, above n 2, 56-57. They also point out that - while they are concerned with the intentions that we have reasonable grounds for attributing to Parliament, which may differ from the intentions Parliament actually had - the exercise of attributing intentions to Parliament presupposes that Parliament is capable of having intentions (at 48).

${ }^{38}$ For a very different account of linguistic content that nevertheless ascribes a crucial role to the speaker's (publicly accessible) intentions, see Patrick Emerton, 'Political Freedoms and Entitlements in the Australian Constitution - An Example of Referential Intentions Yielding Unintended Legal Consequences' (2010) 38 Federal Law Review 169, especially 176-7.

${ }^{39}$ See Campbell and Campbell, above $\mathrm{n}$ 2, for an attempt to show that the meaning of statutory provisions can be identified without appeal to legislative intent (and hence to show that the High Court's scepticism about legislative intent is tenable). However, Campbell and Campbell do not seek to show that the meaning thesis can account for the presumption of mens rea, and it is far from clear that they would be able to do so. While they list several factors that they regard as relevant to identifying a statute's linguistic content, they provide little indication of how those factors are relevant or of how to balance those factors when they conflict.
} 
to be complementary, rather than an alternative, to a focus on the speaker's intentions. ${ }^{40}$ In any case, this common background consists of certain assumptions, beliefs or knowledge shared by the parties, which - in the case of legislation - requires that mental states be ascribed to the legislature (or to a certain subset - eg a majority - of the legislators). Since the High Court's qualms about legislative intent concern the idea of Parliamentary intentions as some sort of 'objective collective mental state', ${ }^{41}$ it seems that those qualms would apply equally to attempts to ascribe other mental states (eg beliefs) to Parliament. Moreover, because these approaches require the audience to share the relevant assumptions, beliefs or knowledge, they raise a further problem for the High Court in accounting for the presumption of mens rea, since they require not only the legislature but also its audience to be aware of that presumption.

One might try to avoid these problems by focusing, not on the legislators (or the legislature as a whole), but rather on the Parliamentary drafter. However, this is unlikely to assist the High Court. The Court's scepticism about legislative intent is based, at least in part, on concerns about ascribing intentions to a group in circumstances where members of the group have differing agendas. ${ }^{42}$ Yet drafters typically work in teams (raising questions about group intentions), and sometimes receive instructions from multiple parties with conflicting agendas. It seems likely, then, that the High Court's reasons for being sceptical about legislative intent also apply to any attempt to ascribe intentions to drafters.

Thus, the High Court's scepticism about legislative intent deprives it of the resources it needs to account for the mens rea example consistently with the meaning thesis. (More generally, it deprives the Court of a plausible account of pragmatic content, of the sort needed to explain how a provision's linguistic content can extend beyond its literal or grammatical meaning.) This means that, if the High Court is to have any hope of holding onto the meaning thesis, it must abandon its scepticism about legislative intent.

\footnotetext{
${ }^{40}$ For example, common knowledge is important for Paul Grice, because he regards the relevant intention of the speaker as being (roughly) to convey certain information to the audience via the audience's recognition of that intention: Paul Grice, Studies in the Way of Words (Harvard University Press, 1989) 92. See also Jeffrey Goldsworthy, 'Implications in Language, Law and the Constitution' in Geoffrey Lindell (ed), Future Directions in Australian Constitutional Law: Essays in Honour of Professor Leslie Zines (Federation Press, 1994) 150, 160-1 regarding the connection between speakers' intentions and background assumptions.

${ }^{41}$ Lacey (2011) 242 CLR 573, 592 (French CJ, Gummow, Hayne, Crennan, Kiefel and Bell JJ).

${ }^{42}$ See, eg, Mills v Meeking (1990) 169 CLR 214, 234 (Dawson J); Wik Peoples v Queensland (1996) 187 CLR 1, 168-9 (Gummow J).
} 
In the Introduction, I suggested that the meaning thesis represents a more fundamental commitment on the part of the High Court than does scepticism about legislative intent. Thus, if persuaded that these two views cannot be held together, the Court might abandon its scepticism about legislative intent in order to hold onto the meaning thesis. However, the challenge posed by the mens rea example goes deeper than showing that the meaning thesis cannot be combined with scepticism about legislative intent. Even if the Court were to abandon its scepticism about legislative intent, it is doubtful whether it could account for the mens rea example consistently with the meaning thesis. ${ }^{43}$

I suggested above that, if not for its scepticism about legislative intent, the High Court could seek to account for the mens rea example on the basis that we have (presumptively) good grounds for attributing to Parliament an intention, when enacting a statutory provision creating a criminal offence, to convey that the provision contains a mens rea requirement. However, Greenberg argues that it is very unlikely that legislators always have the intentions they would need to have for this strategy to work. He contends that it is implausible to claim that legislators are always aware of the presumption of mens rea, let alone that they always intend that criminal statutes be interpreted in accordance with that presumption. After all, he points out, many legislators are not lawyers, and even those who are lawyers do not necessarily have expertise in criminal law. He concludes:

\footnotetext{
It can't seriously be maintained ... that legislators are aware of common law practices concerning when mens rea requirements are presumed and, in light of that awareness, use statutory language without mens rea terms with the intention of imposing mens rea requirements. ${ }^{44}$
}

In presenting this argument, Greenberg focuses on legislators' actual intentions. By contrast, we have seen that the objective communication theory embraced by Ekins and Goldsworthy treats as relevant, not legislators’ actual intentions, but rather the intentions that

\footnotetext{
${ }^{43}$ There are further reasons to investigate whether the mens rea example poses problems for the meaning thesis independent of scepticism about legislative intent. At least one of the newer members of the High Court appears uncomfortable with the view expressed in Lacey: Stephen Gageler, 'Legislative Intention' (2015) 41 Monash University Law Review 1, 12-3. Nevertheless, for most of this article, Gageler J appears to presuppose the meaning thesis (though there are some remarks towards the end (at 16) that are not easily reconcilable with that thesis). Moreover, I suggested (above n 4) that many academic commentators also accept the meaning thesis. Some of those commentators reject scepticism about legislative intent, and so are not vulnerable to the objections presented so far. They are, however, vulnerable to the objections that follow, which raise problems for the meaning thesis that are independent of scepticism about legislative intent.

${ }^{44}$ Greenberg, above n 15, 78.
} 
can reasonably be attributed to them. ${ }^{45}$ However, an intention cannot reasonably be attributed to legislators where there is good reason to believe that they lack that intention. Thus, where legislators are unaware of the presumption of mens rea, the objective communication theory cannot warrant ascribing to them intentions with regard to that presumption.

This objection to the meaning thesis does not depend on any general scepticism about legislative intent. ${ }^{46}$ One can grant that legislators (as a group) are capable of having intentions, and yet deny that they have the specific intentions the High Court needs them to have in order to be able to account for the mens rea example consistently with the meaning thesis.

One might seek to avoid this objection by focusing on the intentions of the drafters, not the legislators. If the High Court was to abandon its scepticism about legislative intent, it could accept that drafters (as a group) have intentions. Moreover, unlike many legislators, drafters are (presumably) aware of the presumption of mens rea. However, an explanation is needed as to why it is appropriate to focus on the drafters' intentions. One possible explanation is suggested by Ekins and Goldsworthy, who argue that the drafters' intentions can be ascribed to Parliament because the drafters are Parliament's 'faithful agents, acting like ghostwriters or speechwriters[.] ${ }^{47}$ Yet this does not justify attributing the drafters' intentions to Parliament in circumstances where the drafters possess knowledge (about the presumption of mens rea) that Parliament lacks. We would not ascribe knowledge possessed by a speechwriter to the actual speaker in circumstances where we have reason to doubt that the speaker possesses that knowledge.

Thus, it seems that the High Court could not account for the mens rea example consistently with the meaning thesis, even if it were to abandon its scepticism about legislative intent. However, I do not wish to place too much weight on this example. When discussing the presumption of mens rea, Greenberg assumes that what is relevant is the intentions of individual legislators. He points out that many legislators are not lawyers, or in any case lack expertise in criminal law, and infers that they are therefore unlikely to intend

\footnotetext{
${ }^{45}$ In fact, Ekins and Goldsworthy focus on the intentions that can reasonably be attributed to Parliament as a whole. I discuss the significance of this below.

${ }^{46}$ Greenberg also objects to views like the meaning thesis by appealing to general scepticism about legislative intent (Greenberg, above $\mathrm{n} 15,78$ ), but that objection is distinct from the one considered in the text.

${ }^{47}$ Ekins and Goldsworthy, above n 2, 54.
} 
that criminal statutes be read in light of the presumption of mens rea. However, there are accounts of legislative intent ('non-aggregative accounts') that deny that it is a (straightforward) function of the intentions of individual legislators. ${ }^{48}$ There are, I think, serious difficulties with at least some existing accounts of this sort. ${ }^{49}$ Nevertheless, that some account of this sort is correct seems plausible, given the difficulties both with scepticism about legislative intent and with aggregative accounts that treat legislative intent as a function of the intentions of some or all individual legislators. ${ }^{50}$ And it is possible that the correct account supports attributing the necessary intention - ie that statutory provisions creating criminal offences be read in light of the presumption of mens rea - to the legislature as a whole, even though some or all legislators lack that intention.

\section{Further Counter-Examples}

I have argued that the High Court cannot hold on to both the meaning thesis and its scepticism about legislative intent, since this combination of views is unable to account for the role that the presumption of mens rea plays in statutory interpretation. I have also argued that the problems with the meaning thesis are not limited to the fact that it cannot be combined with scepticism about legislative intent. Even if the High Court were to abandon its scepticism about legislative intent, it would still struggle to account for the presumption of mens rea consistently with the meaning thesis.

Nevertheless, I finished Section 3 by conceding that, were the High Court to abandon its scepticism about legislative intent, it might be able to account for the mens rea example by appealing to a non-aggregative account of legislative intent. I should emphasise that this is only a possibility. It would need to be shown that a non-aggregative account is correct,

\footnotetext{
${ }^{48}$ See, eg, Richard Ekins, The Nature of Legislative Intent (Oxford University Press, 2012). Ekins claims that all legislators must share a 'standing' intention to enact legislation in accordance with accepted procedures. However, he claims that the 'particular' intentions that Parliament has with regard to a specific statute need not be shared by all (or, perhaps, any) individual legislators.

${ }^{49}$ For a critique of Ekins' theory, see Jeffrey Goldsworthy, 'Legislative Intention Vindicated?' (2013) 33 Oxford Journal of Legal Studies 821, 826-31. Goldsworthy suggests a way of overcoming what he sees as the central problem with Ekins' theory - namely, the absence of a tenable account of how the content of the particular legislative intentions is constituted. Goldsworthy's suggested solution focuses on the intentions of the sub-set of legislators who sponsor the bill, contribute to debate on the bill, etc (at 831-5). However, this would appear to turn Ekins' purportedly non-aggregative theory into an aggregative one. More importantly for our purposes, at this point Greenberg's concerns re-emerge. It is doubtful whether the relevant legislators will always be aware of the presumption of mens rea. Even if the bill's sponsor is, the same may not be true of other legislators who debate the bill, propose amendments, etc.

${ }^{50}$ On the former, see above (and, more generally, Ekins and Goldsworthy, above n 2); on the latter, see, eg, Ronald Dworkin, A Matter of Principle (Harvard University Press, 1985) 38-50.
} 
despite the problems that have been identified with some existing accounts. It would also need to be shown that the correct account supports attributing the necessary intention to the legislature (that statutory provisions creating criminal offences be read in light of the presumption of mens rea). However, we do not need to inquire here as to whether this can be shown. Even if the High Court could, by abandoning its scepticism about legislative intent, account for the mens rea example consistently with the meaning thesis, there are other counter-examples to the meaning thesis that cannot be dealt with by appealing to a nonaggregative account of legislative intent.

Consider, again, how the High Court might seek to account for the mens rea example. It might argue that the presumption of mens rea contributes to the linguistic content of the provision being interpreted because we can reasonably attribute to Parliament an intention to convey that the provision must be read in light of the presumption. If this is plausible, it is only because the presumption of mens rea pre-dates the statutory provisions it affects. Parliament could not intend, when enacting a provision, to convey that it must be read in light of the presumption of mens rea if that presumption did not exist at the time, but rather was introduced into the law after the provision was enacted. ${ }^{51}$

This may not be a significant problem with regard to the presumption of mens rea. There may be few, if any, provisions defining a criminal offence which are still in force today but which were enacted before the presumption of mens rea became part of the law. However, there are other examples where this is a problem. In this Section, I offer three examples of this sort.

In 1981, s 15AA was inserted into the Acts Interpretation Act 1901 (Cth). ${ }^{52}$ In its original form, it read:

\footnotetext{
${ }^{51}$ That it is harder for orthodox approaches to account for the application of principles of statutory interpretation to provisions that pre-date those principles has not, I think, been widely noted. One exception is Aileen Kavanagh, in her discussion of s 3(1) of the UK Human Rights Act: Aileen Kavanagh, Constitutional Review under the UK Human Rights Act (Cambridge University Press, 2009) 99-100.

${ }^{52}$ Equivalent provisions now exist in each State and Territory: Legislation Act 2001 (ACT) s 139; Interpretation Act 1987 (NSW) s 33; Interpretation Act 1987 (NT) s 62A; Acts Interpretation Act 1954 (Qld) s 14A; Acts Interpretation Act 1915 (SA) s 22; Acts Interpretation Act 1931 (Tas) s 8A; Interpretation of Legislation Act 1984 (Vic) s 35(a); Interpretation Act 1984 (WA) s 18.
} 
In the interpretation of a provision of an Act, a construction that would promote the purpose or object underlying the Act (whether that purpose or object is expressly stated in the Act or not) shall be preferred to a construction that would not promote that purpose or object.

Section 15AA was enacted against a background of public criticism of the High Court for interpreting taxation statutes in a way that was consistent with their literal meaning, but which facilitated tax minimisation in a way that was contrary to the purpose of those statutes. ${ }^{53}$ The new section meant that, where there was another available interpretation of a provision that did promote the statutory purpose, courts were required to prefer that interpretation to a literal construction that did not promote the statutory purpose. Thus, the motivation behind the introduction of s 15AA was to change the way in which statutory interpretation was practised by the courts.

The change was, however, a limited one. It did not require the court to adopt whichever interpretation would best promote the purpose of the statute being interpreted. Rather, it mandated a certain interpretive choice only where the court was confronted with two open interpretations, one of which would promote the statutory purpose and the other of which would not. ${ }^{54}$ In 2011, s 15AA was amended to remove this limitation. It now reads:

In interpreting a provision of an Act, the interpretation that would best achieve the purpose or object of the Act (whether or not that purpose or object is expressly stated in the Act) is to be preferred to each other interpretation.

Thus, where there are two (or more) interpretations, each of which would promote the statutory purpose, courts are now required to choose the interpretation that would best promote that purpose.

Crucially for our purposes, s 15AA applies not only to statutory provisions enacted after 1981, but also to provisions enacted before s 15AA came into force. ${ }^{55}$ Thus, its introduction in 1981 changed the way in which certain pre-existing provisions should be interpreted, and hence changed their legal effect. Similarly, the amendment in 2011 changed

\footnotetext{
${ }^{53}$ See DC Pearce and RS Geddes, Statutory Interpretation in Australia (LexisNexis Butterworths, $8^{\text {th }}$ ed, 2014) 41.

${ }^{54}$ See the discussion of the Victorian equivalent of s 15AA in Chugg v Pacific Dunlop Ltd (1990) 170 CLR 249, 262 (Dawson, Toohey and Gaudron JJ).

${ }^{55}$ GTK Trading Pty Ltd v Export Development Grants Board (1981) 56 FLR 292.
} 
the way in which certain pre-2011 provisions should be interpreted - namely, provisions for which there were multiple open interpretations, each of which would, to varying degrees, promote the statutory purpose.

However, the introduction of s 15AA in 1981 (and its amendment in 2011) did not change the linguistic content of the pre-existing provisions whose legal effect it altered. It could not alter their semantic content. Nor can the operation of s 15AA be explained in the way that the presumption of mens rea can (perhaps) be accounted for. ${ }^{56}$ It is difficult to argue that, when enacting the earlier provision that is now subject to s 15AA, Parliament intended to convey that it should be read in light of s 15AA, given that s 15AA did not yet exist (or did not yet exist in its current form). Thus, it seems that s 15AA produces a divergence between the legal effect of certain pre-existing provisions and their linguistic content, contrary to the meaning thesis. ${ }^{57}$

It might be objected that s 15AA was designed to correct a judicial misconception about how to interpret statutes, rather than changing the legal effect of any statutory provision. To the extent that judges were placing too much emphasis on literal meaning, and were overlooking the importance of statutory purpose, they were mistaken in law. The role of s 15AA, on this story, was to correct that mistake. In doing so, it reflected what the law has always been, and so did not change the legal effect of any provision so as to produce a divergence between the provision’s legal effect and its linguistic content.

However, this objection overlooks the fact that there have been two versions of $\mathrm{s}$ 15AA. The amended, 2011 version is wider in scope than the original, 1981 version, and so it cannot be the case that neither changed the legal effect of pre-existing provisions. In fact, we shall see in Section 5A that there is reason to think that both versions of s 15AA went beyond

\footnotetext{
${ }^{56} \mathrm{I}$ am concerned in the text with the effect of s 15AA on pre-existing provisions. The meaning thesis may (perhaps) be able to account for the effect of s 15AA on provisions enacted after the introduction of s 15AA, in the same the way that it may (perhaps) be able to account for the mens rea example.

${ }^{57}$ Perhaps Parliament intended that the earlier provision be read in light of any future changes to the law. (I am grateful to Jeremy Gans for suggesting this possibility.) Let us leave to one side the question of whether Parliament had any such intention, and communicated it in the way necessary for it to form part of the linguistic content of the earlier provision. The fundamental problem with this suggestion is that such an intention is too general to generate the necessary linguistic content. For the effect of s 15AA on the earlier provision to be reflected in that provision's linguistic content, Parliament must (at the time of enacting the earlier provision) have had communicative intentions about how future changes to the law would affect the provision. If Parliament did not anticipate the particular changes that occurred, and simply intended that the earlier provision be read in light of future changes to the law, whatever they may be, then this condition is not met.
} 
simply restating the old common law position concerning the importance of statutory purpose. If so, both versions changed the legal effect of provisions subject to s 15AA, rather than simply correcting an erroneous practice on the part of judges.

Having presented s 15AA in some detail, let me offer two further examples. Reasons of space preclude me from discussing these examples in as much detail, but I hope to show that it is plausible to treat them as further counter-examples to the meaning thesis.

Section 15AA is not the only statutory provision that seeks to govern the proper interpretation of other provisions. A more controversial example is s 32(1) of the Charter of Human Rights and Responsibilities Act 2006 (Vic), which states: ${ }^{58}$

So far as it is possible to do so consistently with their purpose, all statutory provisions must be interpreted in a way that is compatible with human rights.

Section 3(1) defines 'human rights' as those rights set out in Part 2 of the Charter. Thus, on its face, s 32(1) requires every statutory provision in Victoria to be interpreted in a way that is compatible with the rights set out in the Charter, so far as it is possible to do so consistently with the purpose of the provision being interpreted. Moreover, s 49(1) makes it clear that s 32(1) applies not only to statutes passed after the commencement of the Charter, but also to statutes passed before the Charter commenced.

Thus, s 32(1) altered the legal effect of certain pre-existing provisions - namely, those that were not rights-compliant before the introduction of the Charter, but which can now be given a rights-compliant interpretation consistently with their purpose. However, s 32(1) did not contribute to the linguistic content of those provisions. Parliament's communicative intentions with regard to these provisions were formed before s 32(1) was enacted, and so cannot take account of the way in which s 32(1) subsequently altered the legal effect of those provisions. (This is most obviously true with regard to statutes enacted before the introduction of the Charter was even contemplated. However, even with regard to statutes enacted shortly before the Charter, it is unlikely that Parliament intended, when enacting

\footnotetext{
58 Similar provisions exist in other jurisdictions, both in Australia (Human Rights Act 2004 (ACT) s 30) and overseas (eg Human Rights Act 1998 (UK) s 3; New Zealand Bill of Rights Act 1990 s 6). How similar these provisions are to s 32(1) of the Charter is the subject of debate, which I will not enter into here.
} 
those statutes, to convey that their legal effect would be subject to a proposed Act that was not yet part of Victorian law.)

Hence, s 32(1) produces a divergence between the legal effect and linguistic content of certain pre-existing provisions, contrary to the meaning thesis. Admittedly, there is some overlap between s 32(1) and the principle of legality, especially if that principle is understood as requiring that statutes be interpreted in a way that is compatible with fundamental common law rights and freedoms, unless Parliament clearly expresses a contrary intention. ${ }^{59}$ This may mean that some provisions that pre-date the Charter, and that can be given a rights-compliant interpretation under the Charter, already had such an interpretation due to the principle of legality. If so, s 32(1) did not alter their legal effect. However, the overlap between s 32(1) and the principle of legality is only partial. At the very least, s 32(1) protects a broader range of rights than the principle of legality. ${ }^{60}$ Thus, the introduction of s 32(1) changed the legal effect of some pre-existing provisions - namely, those that were not previously compatible with the Charter rights, even taking the principle of legality into account, but which can be interpreted in a rights-compliant way consistently with their purpose. However, s 32(1) cannot affect the linguistic content of those provisions, for the reasons given above.

For a different type of example, consider the practice of consulting statutes in pari materia to help ascertain the legal effect of the statute being interpreted ('the primary statute'). ${ }^{61}$ Where the statutes in pari materia were enacted before the primary statute, they may (perhaps) form part of the background which helped shape Parliament's communicative intentions when it enacted the primary statute. However, where the statutes in pari materia were enacted after the primary statute, it cannot be the case that they helped shape Parliament's communicative intentions when enacting the primary statute, and yet they may help determine the legal effect of that statute. In such cases, it seems, we have a further counter-example to the meaning thesis. ${ }^{62}$

\footnotetext{
59 X7 v Australian Crime Commission (2013) 248 CLR 92, 153 (Kiefel J). There are other ways of understanding the principle of legality which may reduce the overlap with s 32(1).

${ }^{60}$ Momcilovic (2011) 245 CLR 1, 50 (French CJ), 203 (Crennan and Kiefel JJ). That s 32(1) goes further than the principle of legality is also central to Heydon J's dissent in Momcilovic (see, especially, at 181-2), and is supported by the Explanatory Memorandum (Explanatory Memorandum, Charter of Human Rights and Responsibilities Bill 2006 (Vic), 23) and the Second Reading Speech (Victoria, Parliamentary Debates, Legislative Assembly, 4 May 2006, 1290 (Rob Hulls)).

${ }^{61}$ See Pearce and Geddes, above $n$ 53, 128-9 for a discussion of this practice.

${ }^{62}$ Cf Antonin Scalia and Bryan A Garner, Reading Law: The Interpretation of Legal Texts (Thomson/West, 2012) 252, who argue that the in pari materia principle cannot reflect legislative intent, irrespective of whether
} 
It might be objected that, where the statutes in pari materia were enacted after the primary statute, they are relevant only in so far as they provide evidence of what Parliament intended when it enacted the primary statute. On this view, just as we can look to a speaker's subsequent statements to obtain a better understanding of what she intended to communicate by an earlier utterance, we can look to later enactments by Parliament to better understand its communicative intentions when it enacted an earlier statute. Consideration of those statutes for this purpose is consistent with the meaning thesis.

However, it does not seem very promising to try to explain courts' reliance on later statutes in pari materia on the basis that they shed light on Parliament's intentions when enacting the earlier statute. There will often be reason to think that Parliament's intentions have changed in the meantime, and yet there may be good reasons to consider the later statutes (based, for example, on the need for consistency in the law).

\section{Can the Meaning Thesis Account for These Counter-Examples?}

\section{A. The reading down strategy}

In this Section, I consider three ways in which one might try to save the meaning thesis from the counter-examples presented in Section 4. The first is the 'reading down strategy', which seeks to show that provisions like s 15AA of the Acts Interpretation Act have a narrower scope of operation than might first appear. In this way, it seeks to show that the operation of those provisions is consistent with the meaning thesis, since they do not change the legal effect of other provisions in a way that results in a divergence between those provisions' legal effect and their linguistic content. Importantly, the strategy appears to derive support from the way in which the High Court has interpreted both s 15AA of the Acts Interpretation Act and s 32(1) of the Charter. ${ }^{63}$

the statute in pari materia was enacted before or after the primary statute. This is, they claim, because it is implausible to say that the legislature knew of all the related legislation that existed when it enacted the primary statute, and because it is impossible to say that it knew of related legislation that is only subsequently enacted.

${ }^{63}$ It is hard to see how the reading down strategy could apply to the third example presented in Section 4 namely, the in pari materia principle. I shall not pursue this concern here, however. 
Let us begin by considering s 15AA. There are several suggestions in the case law as to how s 15AA can be read down so that it is consistent with the meaning thesis, and I cannot discuss all of them here. ${ }^{64}$ Instead, I will focus on a recent suggestion contained in the unanimous judgment of the High Court in Thiess. The Court stated that:

\begin{abstract}
Objective discernment of statutory purpose is integral to contextual construction. The requirement of s 15AA of the Acts Interpretation Act 1901 (Cth) that 'the interpretation that would best achieve the purpose or object of [an] Act (whether or not that purpose or object is expressly stated) is to be preferred to each other interpretation' is in that respect a particular statutory reflection of a general systemic principle. For 'it is one of the surest indexes of a mature and developed jurisprudence not to make a fortress out of the dictionary; but to remember that statutes always have some purpose or object to accomplish, whose sympathetic and imaginative discovery is the surest guide to their meaning. ${ }^{65}$
\end{abstract}

One possible reading of this passage is that s 15AA reflects a general principle that would be part of the law even in s 15AA's absence - namely, that a careful consideration of the statutory purpose provides a reliable guide to the linguistic content of the provision being interpreted. If so, s 15AA does not change the legal effect of the provisions to which it applies, including provisions that pre-date it, and so cannot result in the legal effect of those provisions diverging from their linguistic content. ${ }^{66}$

However, the meaning thesis is meant to apply, not only to the provisions that are subject to s 15AA, but also to s 15AA itself. Section 15AA is, after all, a statutory provision that - according to the meaning thesis - has a legal effect that is equivalent to its linguistic content. However, on the interpretation suggested in the previous paragraph, Thiess attributes to s 15AA a legal effect that departs from its linguistic content. On that view, s 15AA does not change the law; rather, it reflects a general (pre-existing) principle that a careful consideration of statutory purpose provides a reliable guide to identifying a provision's linguistic content. Yet, at first glance, this is not what s 15AA says. Rather, it says that we

\footnotetext{
${ }^{64}$ One possibility is that s 15AA does not itself alter the legal effect of pre-existing provisions, but rather directs the court to make new law by adopting whichever interpretation would best promote the statutory purpose. I discuss whether the meaning thesis can be saved by interpreting provisions like s 15AA in this way in Dale Smith, 'The Meaning of a Statute and the Content of the Law' (unpublished manuscript). Here, it is enough to note that many of the considerations that make the meaning thesis seem appealing in the first place (see Section 2B) militate against interpreting s 15AA as conferring on courts a broad power to make new law to promote the purpose of the provisions they interpret.

65 (2014) 250 CLR 664, 672 (quoting from Cabell v Markham (1945) 148 F 2d 737, 739).

${ }^{66}$ This interpretation of s 15AA bears obvious similarities to the one rejected in Section 4, and I suggest below that it is vulnerable to a similar objection.
} 
must interpret statutes in the way that would best achieve their purpose. Moreover, given what we know about the motivation behind its introduction, we cannot reasonably ascribe to Parliament an intention to communicate that s 15AA does not change the way in which statutes are to be interpreted, but simply reminds us of the usefulness of considering purpose when ascertaining the meaning of statutory provisions. Thus, the reading down of s 15AA in Thiess results in that section being given a legal effect that departs from its linguistic content.

In any case, the High Court's interpretation of s 15AA in Thiess is questionable. The Court claimed that s 15AA reflects a general principle that would be part of the law even in s 15AA's absence. However, this overlooks the fact that there have been two versions of $\mathrm{s}$ 15AA. We saw in Section 4 that the amended, 2011 version is broader than the original, 1981 version, and so they cannot both reflect the same principle - namely, that a careful consideration of purpose provides a reliable guide to identifying linguistic content.

Indeed, while there was a common law principle that existed before s 15AA and that permitted consideration of statutory purpose, arguably that principle differed from either version of s 15AA. On one view, the common law principle permitted a consideration of purpose only where there was some ambiguity on the face of the provision being interpreted, whereas s 15AA permits consideration of purpose in deciding whether there is ambiguity in the first place. ${ }^{67}$ Even if one allows that the position at common law was uncertain, ${ }^{68}$ it might still be said that s 15AA eliminates that uncertainty. Either way, s 15AA changed the legal effect of at least some pre-existing provisions - namely, those that would have been interpreted differently, or whose proper interpretation would have been uncertain, under the common law principle.

However, the High Court may ascribe a more complex role to s 15AA than a superficial reading of the passage in Thiess suggests. On this alternative reading, we begin by considering the text, context and (as reflected in s 15AA) the purpose of a statutory provision. Sometimes, an examination of these factors - in particular, purpose - reveals that the provision's linguistic content is unambiguous. These are the cases that the Court had in mind in the passage from Thiess quoted earlier. However, on other occasions, an examination of

\footnotetext{
${ }^{67}$ This was the view of Dawson J in Mills v Meeking (1990) 169 CLR 214, 235, with regard to the Victorian equivalent of s 15AA.

${ }^{68}$ See Pearce and Geddes, above n 53, 43-5.
} 
these factors reveals that the provision's linguistic content is ambiguous. In these cases, the amended version of s 15AA, with which the High Court was concerned in Thiess, requires a court to adopt the interpretation that best promotes the purpose of the provision being interpreted. Here, s 15AA is more than just a guide to the linguistic content of that provision; it results in the provision having a determinate legal effect, despite the ambiguity in the provision’s linguistic content.

This interpretation of s 15AA may reduce the gap between the section's legal effect and its linguistic content, but does not eliminate that gap. It ascribes to s 15AA a dual role: sometimes, the section serves to remind us that a consideration of purpose may reveal that an ambiguity is only apparent; at other times, it provides a way of resolving a genuine ambiguity. The latter role may match s 15AA's linguistic content, but - on this interpretation - that is only part of s 15AA's legal effect, and so it cannot be said that s 15AA's overall legal effect matches its linguistic content. The wording of s 15AA does not distinguish between two types of case to which the section applies. Nor does it refer to treating purpose as a reliable guide to identifying linguistic content in cases where this reveals that any ambiguity is only apparent. And we have been offered no reason to think that Parliament intended to convey that s 15AA would play this dual role.

Moreover, this interpretation of s 15AA gives rise to a further problem for the meaning thesis, because it entails that the legal effect of some of the provisions that are subject to s 15AA differs from their linguistic content. Where there is genuine ambiguity in an earlier provision, s 15AA changes that provision's legal effect. Prior to the enactment of s 15AA, the provision has an indeterminate legal effect, matching its ambiguous linguistic content. (Or so the meaning thesis requires us to assume. If a provision's linguistic content is ambiguous, the meaning thesis entails that its legal effect must be similarly indeterminate.) After the enactment of (the amended version of) s 15AA, the provision has whatever legal effect best promotes its purpose. However, s 15AA does not change the provision's linguistic content, which remains ambiguous. Thus, the operation of s 15AA results in a divergence between the provision's (ambiguous) linguistic content and its (now determinate) legal effect, contrary to the meaning thesis.

The reading down strategy has also been applied to s 32(1) of the Charter. Having considered the application of the strategy to s 15AA of the Acts Interpretation Act in some 
detail, I shall confine myself to a few brief remarks about its application to s 32(1), focusing particularly on the High Court's treatment of that section in Momcilovic. ${ }^{69}$ The majority judges sought to read down s 32(1), but disagreed about how to do so. Gummow J treated it as another example of a canon of construction that, in accordance with Project Blue Sky, may warrant attributing to a provision a linguistic content that differs from its literal or grammatical meaning. ${ }^{70}$ On this view, s 32(1) contributes to the provision's linguistic content, and so cannot produce a divergence between the provision's legal effect and linguistic content. However, Gummow J does not explain how s 32(1) could contribute to the linguistic content of a provision that was enacted before s 32(1) was. Nor is it enough to say that the introduction of s 32(1) changed the context in which the earlier provision is to be interpreted. To save the meaning thesis, one needs to explain how that change in context bears on the linguistic content of the earlier provision, given that the change occurred after the provision was enacted.

French CJ, Crennan and Kiefel JJ read down s 32(1) in a different way. While their Honours insisted that s 32(1) cannot require that a provision with determinate linguistic content be given a legal effect that departs from that linguistic content, ${ }^{71}$ they also acknowledged that not all statutory provisions have determinate linguistic content. Some are ambiguous or vague. Section 32(1), they suggested, provides a reason to interpret an ambiguous or vague provision as having a determinate legal effect, one that is compatible with the Charter rights. ${ }^{72}$

This interpretation of s 32(1) raises the same problems for the meaning thesis as the more sophisticated understanding of the High Court's treatment of s 15AA in Thiess. First, it entails that the legal effect of ambiguous, pre-Charter provisions differs from their linguistic

\footnotetext{
${ }^{69}$ It is worth noting, though, that English courts have largely eschewed the reading down strategy with regard to the UK equivalent of s 32(1): see, especially, Ghaidan v Godin-Mendoza [2004] UKHL 30.

${ }^{70}$ Momcilovic (2011) 245 CLR 1, 92. Hayne J expressed agreement with Gummow J on this point (at 123).

${ }^{71}$ Indeed, it was common ground among the judges in Momcilovic that, if s 32(1) required a court to depart from the determinate linguistic content of the provision it was interpreting, in order to give that provision a rightscompliant interpretation, then s 32(1) would be unconstitutional (since it would require judges to exercise legislative power). Heydon J, in dissent, was particularly clear on this point (Momcilovic (2011) 245 CLR 1, 158, 181-4), but see also at 92 (Gummow J, with Hayne J concurring on this point), 208, 211, 221 (Crennan and Kiefel JJ).

${ }^{72}$ Momcilovic (2011) 245 CLR 1, 50 (French CJ), 221 (Crennan and Kiefel JJ). Bell J is less clear on this point, but I think that her Honour also holds this view (at 250).
} 
content. Section 32(1) results in such provisions having determinate (rights-compliant) legal effect, even though their linguistic content remains ambiguous. ${ }^{73}$

Second, to hold that s 32(1) only alters the legal effect of ambiguous provisions is to attribute to s 32(1) a legal effect that conflicts with its linguistic content. Prima facie, the words used in s 32(1) express a requirement that all Victorian provisions be given a rightscompliant interpretation. By contrast, the reading down strategy endorsed by French CJ, Crennan and Kiefel JJ effectively treats s 32(1) as applying only to ambiguous provisions.

Of course, the requirement in s 32(1) is qualified. Statutory provisions must be given a rights-compliant interpretation so far as it is possible to do so consistently with their purpose. However, it is not obvious that this justifies interpreting s 32(1) as applying only to ambiguous provisions. The majority in Momcilovic, in effect, takes the qualifying clause in s 32(1) to mean 'so far as it is possible to do so consistently with orthodox principles of statutory interpretation', ${ }^{74}$ which - as we have seen - are understood by the High Court to require that provisions be given a legal effect that corresponds to their linguistic content. Perhaps this supports reading s 32(1) as applying only to ambiguous provisions. However, the majority's interpretation is contrary to the linguistic content of s 32(1), which refers to purpose, not to orthodox principles of statutory interpretation. ${ }^{75}$ Recall that, on the approach in Project Blue Sky, consideration of purpose is only one factor that can cause a provision's legal meaning to depart from its literal or grammatical meaning. It follows that a reference to purpose cannot be taken to be a reference to orthodox principles of statutory interpretation more generally. ${ }^{76}$ This suggests that the reading down strategy endorsed by French CJ, Crennan and Kiefel JJ gives a legal effect to s 32(1) that conflicts with its linguistic content.

\footnotetext{
${ }^{73}$ One might seek to avoid this conclusion by denying that s 32(1) changes the legal effect of ambiguous preCharter provisions, instead interpreting it as a direction to the court to make new law to resolve the ambiguity in a way that is right-compliant. See above n 64 regarding the problems with that suggestion.

${ }^{74}$ Momcilovic (2011) 245 CLR 1, 50 (French CJ), 92 (Gummow J), 123 (Hayne J), 210 (Crennan and Kiefel JJ), 250 (Bell J). Crennan and Kiefel JJ base their interpretation of s 32(1), not only on the qualifying clause, but also on the fact that $\mathrm{s} 32(1)$ is expressed as a directive as to how statutory provisions are to be 'interpreted', which they take to be a reference to the ordinary process of statutory interpretation (at 210). However, it is unclear what role the qualifying clause is meant to play if one takes the reference to 'interpretation' in s 32(1) as bringing into play all the factors mentioned in Project Blue Sky.

${ }^{75}$ Heydon J makes a similar point in dissent: Momcilovic (2011) 245 CLR 1, 178-9, 181.

${ }^{76}$ It might be argued that the word 'purpose' is used differently in s 32(1) than in Project Blue Sky. However, there is evidence that Parliament intended that s 32(1) would change how statutory provisions are interpreted (see the references to the Explanatory Memorandum and Second Reading Speech in above n 60). Reading the qualifying clause in s 32(1) as requiring conformity to orthodox principles of statutory interpretation flies in the face of that intention.
} 
Finally, let us consider a variation on the reading down strategy. I have suggested that there are problems with confining the application of $s$ 32(1) to ambiguous provisions. However, one might object that, if s 32(1) requires judges to give (some) determinate provisions a legal effect that does not match their linguistic content, then s 32(1) is unconstitutional, because it requires judges to exercise legislative power. ${ }^{77}$ Similar concerns might be expressed about s 15AA of the Acts Interpretation Act. However, this appears to presuppose, rather than support, the meaning thesis. Why would we think that to require judges to give certain provisions a legal effect that does not match their linguistic content is to require judges to exercise legislative power, unless we already accept the meaning thesis? Conversely, are not the reasons I have given for rejecting the meaning thesis also reasons for rejecting the claim that, when interpreting statutory provisions, judicial power is limited to giving those provisions a legal effect that corresponds to their linguistic content?

These questions are all the more pressing because one must pay a steep price to hold onto the dogma that the court's role is simply to ascertain the meaning of the words contained in the statute. ${ }^{78}$ On this view, Parliament lacks the power to direct courts to interpret statutory provisions in a way that conflicts with orthodox principles of statutory interpretation (principles that are largely judge-made). Arguably, if Parliament lacks control over how the statutes it enacts are to be interpreted, then this undermines the point of conferring legislative power on Parliament in the first place. At the very least, it represents a significant limitation on Parliament's law-making power, and so sits uneasily with one of the main attractions of the meaning thesis - namely, that it purports to respect, not abridge, Parliamentary supremacy.

\section{$B$. The repeal and replacement strategy}

Rather than reading down s 15AA of the Acts Interpretation Act in an attempt to show that it does not alter the legal effect of the provisions to which it applies, one might look for another way of defending the meaning thesis. Consider the application of the original version of $\mathrm{s}$ 15AA to a pre-1981 provision that had previously been given a construction by a court that

\footnotetext{
${ }^{77}$ This was Heydon J's view in Momcilovic. The majority judges might also be tempted by this objection: see above $\mathrm{n} 71$.

${ }^{78}$ Especially since this dogma needs to be qualified anyway. A statute's linguistic content will not supply an answer to every legal question pertaining to that statute, and so judges sometimes need to make new law to fill a gap in the statute.
} 
did not promote the statutory purpose. (For the sake of the example, assume that the court was right to do so, given the state of the law before s 15AA was introduced.) One might argue that s 15AA implicitly repealed the pre-1981 provision and replaced it with a new provision that does promote the statutory purpose. ${ }^{79}$ I shall refer to this as the 'repeal and replacement' strategy. ${ }^{80}$ Because the pre-1981 provision has been repealed, the meaning thesis does not apply to it. (The meaning thesis provides an account of the legal effect of valid statutory provisions.) Thus, it does not matter that the provision's linguistic content fails to take account of the operation of s 15AA. By contrast, the linguistic content of the new provision ('the replacement provision') can take account of s 15AA, because the replacement provision was introduced into the law at the same time as s 15AA. Thus, the linguistic content of the replacement provision may match its legal effect.

Section 15AA does not state what the replacement provision is. It states that statutory provisions must be given an interpretation that promotes the statutory purpose, but does not specify what that interpretation is. However, perhaps the replacement provision exists as an implicature of s 15AA: it is not part of what s 15AA says, but is implied by what that section says. ${ }^{81}$ The implicature arises, one might argue, because s 15AA says that the pre-1981 provision must be read in a way that promotes the statutory purpose, but does not say what that reading is, in circumstances where we expect the legislature to give detailed guidance. We therefore take Parliament to have communicated the content of the replacement provision by implication.

However, what determines the linguistic content (and hence, according to the meaning thesis, the legal effect) of the replacement provision? According to the objective communication theory, implicatures - like what was said - are fixed by reference to the communicative intentions we can reasonably attribute to the speaker (though, in the case of implicatures, the relevant intention is to communicate something by implication) ${ }^{82}$ However, the linguistic content of the replacement provision cannot be determined by reference to the communicative intentions that Parliament could reasonably be regarded as having when it

\footnotetext{
${ }^{79}$ One cannot claim, consistently with the meaning thesis, that s 15AA amended the pre-1981 provision, unless one can show that it altered the provision's linguistic content. For the reasons already given, this is unlikely.

${ }^{80} \mathrm{I}$ am grateful to Farrah Ahmed, Patrick Emerton and Jeremy Gans for pressing me to address this strategy.

${ }^{81}$ Concerning implicatures and how they differ from what was said, see Grice, above n 40, ch 2; Goldsworthy, above n 40, 152-61.

${ }^{82}$ Ekins and Goldsworthy, above n 2, 56.
} 
enacted the pre-1981 provision, since (we are assuming) this provision has been repealed. In any event, those intentions would not take account of the subsequent introduction of s 15AA.

It is more plausible to claim that the linguistic content of the replacement provision is determined by reference to the communicative intentions that Parliament could reasonably be regarded as having when it enacted s 15AA. Parliament did not state what the replacement provision is, but perhaps it intended to communicate, by implication, the content of that provision. However, this suggestion, too, is problematic. Parliament could reasonably be taken to have desired that an interpretation of the pre-1981 provision that promotes the statutory purpose be found, but it is highly unlikely that it had communicative intentions that specify what that interpretation is. There is no evidence that Parliament identified, in a systematic way, which of the vast number of pre-1981 provisions would have their legal effect altered by s 15AA, let alone that it decided what interpretation each of those provisions should be given to promote the relevant statutory purpose. And recall that, on the objective communication theory, we cannot reasonably attribute to Parliament intentions that it clearly did not have. Since Parliament clearly did not intend to convey what interpretation each of these pre-1981 provisions should be given, such an intention cannot reasonably be attributed to Parliament.

One might think that it is enough that, for each of these provisions (whatever they may be), there is an interpretation that promotes the relevant statutory purpose. Parliament can, one might think, be taken to have intended to communicate that this interpretation (whatever it may be) should be upheld. ${ }^{83}$ However, even if we can reasonably attribute that intention to Parliament, it will not suffice for present purposes. On the view under consideration, the content of the replacement provision is specified by the communicative intentions that can reasonably be attributed to Parliament when enacting s 15AA. Yet those intentions do not specify the content of the replacement provision if they amount only to an intention that the interpretation that promotes the relevant statutory purpose - whatever that interpretation may be - should be upheld. In such a case, Parliament cannot be taken to have intended to communicate what that interpretation is.

\footnotetext{
${ }^{83}$ Alternatively, one might claim that s 15AA directs the court to supply the replacement provision. However, this reading of s 15AA is problematic for the reasons given at above $n$ 64. In addition, it would mean that, until the court makes its decision, there is no relevant law, because (according to the repeal and replacement strategy) the pre-1981 provision was repealed by s 15AA.
} 
Moreover, we cannot infer from the fact that Parliament intended that the interpretation (whatever it may be) that promotes the relevant statutory purpose be upheld that it intended that the particular interpretation that promotes that purpose be upheld. It may have been mistaken about which interpretation promotes that purpose or, more likely, may have failed to consider the matter at all.

The problems with the repeal and replacement strategy arise, not because it claims that s 15AA implicitly repealed certain pre-1981 provisions, but because it claims that those provisions were replaced by new provisions which take into account the operation of s 15AA but which are not expressly stated. The crucial problem is the lack of any plausible account of how the linguistic content of these implicit replacement provisions is generated. Thus, a similar problem does not arise in standard cases of implicit repeal (eg lex posteriori), where either there is no replacement provision or the replacement provision is expressly stated. (In the case of lex posteriori, it is stated in the later, explicitly enacted, statute that prevails over the earlier, implicitly repealed, statute.)

\section{The concession and avoidance strategy}

Another strategy open to the High Court, in defending the meaning thesis, is to concede that provisions such as s 15AA of the Acts Interpretation Act produce a divergence between the legal effect and linguistic content of certain statutory provisions, but to insist that this is merely the exception that proves the rule. On this view, the claim that a provision's legal effect is equivalent to its linguistic content was only ever meant to be a generalisation. Of course, there are exceptions to that claim, and the operation of s 15AA on certain pre-existing provisions represents one such exception. I shall call this the 'concession and avoidance' strategy.

Certainly, the High Court recognises exceptions to the meaning thesis. We have seen that some High Court judges concede that a provision's legal effect may depart from its linguistic content if its linguistic content is ambiguous. Further, in Momcilovic, Crennan and Kiefel JJ allude to the possibility that, even if a provision's linguistic content is determinate, a 
court should not uphold that linguistic content if doing so would defeat the statutory purpose. ${ }^{84}$

However, it is not sufficient simply to assert that the operation of provisions like s 15AA represents a further exception to the meaning thesis. We need a principled explanation of why this exception should be recognised, in order for this strategy to amount to more than merely an ad hoc response to the counter-examples presented in Section 4.

Perhaps the most promising way of showing that the operation of provisions like s 15AA represents a principled exception to the meaning thesis involves appeal to the doctrine of parliamentary supremacy. ${ }^{85}$ Recall that this doctrine helps explain why the meaning thesis appears attractive. One might argue that it also entails that, while legislation generally has the legal effect that Parliament intended to convey that it would have, Parliament has the power subsequently to modify that legal effect. Section 15AA of the Acts Interpretation Act and s 32(1) of the Charter should be viewed as exercises of that power by the legislature. Thus, they count as principled exceptions to the meaning thesis, because their role is explained by reference to the same doctrine that supports that thesis.

This is an interesting argument. However, it is less plausible when applied to the in pari materia principle. Whereas, arguably, s 15AA and s 32(1) represent a deliberate choice by Parliament to give certain pre-existing provisions a legal effect that differs from their linguistic content, the enactment of a later statute in pari materia may alter the legal effect of an earlier statute without Parliament being aware of this consequence.

Even if we focus on s 15AA and s 32(1), I doubt that the appeal to parliamentary supremacy succeeds in showing that these sections are exceptions, rather than counterexamples, to the meaning thesis. If Parliament has the power to give a legal effect to statutory provisions that departs from their linguistic content, then whether the meaning thesis is true even as a generalisation depends on the extent to which Parliament has exercised that power. Section 15AA and s 32(1) provide reason to think that at least some Australian legislatures have exercised that power to such an extent that the meaning thesis is not true even as a generalisation. The scope of these sections is very broad. For example, s 32(1) applies to all

\footnotetext{
${ }^{84}$ Momcilovic (2011) 245 CLR 1, 221.

${ }^{85}$ This line of thought was suggested in conversation by Jeff Goldsworthy.
} 
Victorian provisions, and so changes the legal effect of every pre-Charter provision that was not previously rights-compliant but which can be given a rights-compliant interpretation consistently with its purpose. Similarly, s 15AA alters the legal effect of a broad range of Commonwealth provisions enacted before 1981 or 2011 (depending on whether we focus on the original or amended version of s 15AA). ${ }^{86}$

Moreover, s 15AA and s 32(1) are far from unique. Any law - whether contained in a statute or not - that alters the contribution to the law made by pre-existing statutory provisions will produce a divergence between the legal effect of those provisions and their linguistic content, and hence represent a counter-example to the meaning thesis. It seems likely that the number of such laws in force today, and the range of provisions they affect, is such that we cannot plausibly regard them as exceptional.

In Section 4, I suggested that such laws include, not only s 15AA and s 32(1), but also later statutes in pari materia. I shall not seek to provide a longer list here, since each item on the list would require separate explanation and defence. However, I shall finish by mentioning a particularly interesting candidate for inclusion on the list - namely, the principle of legality. Where the principle of legality applies to provisions that were enacted after the principle became part of Australian law, this raises the same sorts of issues as the mens rea example discussed in Section $3 .{ }^{87}$ However, there may be some provisions, the proper interpretation of which is affected by the principle of legality, but which were enacted prior to the existence of that principle. If so, the application of the principle of legality to those provisions represents a counter-example to the meaning thesis of the same sort as the counter-examples discussed in Section 4.

\footnotetext{
${ }^{86}$ As we have seen, the introduction of s 15AA in 1981 altered the legal effect of all those provisions that had previously been given a literal construction that did not promote the statutory purpose, where there was another available interpretation that did promote that purpose. Arguably, this included a broad range of taxation (and other) provisions. The 2011 amendment altered the legal effect of a further set of provisions - namely, those for which there were multiple open interpretations, each of which would, to varying degrees, promote the statutory purpose.

${ }^{87}$ Though note that the modern trend may be towards viewing the principle of legality, not as shedding light on Parliament's intentions, but rather as justified on normative grounds (to ensure that Parliament considers the impact of legislation on certain rights and freedoms): Brendan Lim, 'The Normativity of the Principle of Legality' (2013) 37 Melbourne University Law Review 372. This makes it hard to view the principle of legality as contributing to the linguistic content of statutory provisions. One possibility is that the application of the principle to any statute should be regarded as an exception to the meaning thesis, but this would only reinforce the point in the text that the exceptions to that thesis appear to be multiplying rapidly.
} 
Whether this is so is complicated by the fact that there is room for disagreement about when the principle of legality became part of Australian law. Was this when it began to be regularly invoked by the High Court in the late 1980 s and early $1990 \mathrm{~s},{ }^{88}$ when it was first relied on by the High Court in $1908,{ }^{89}$ or earlier still ${ }^{90}$ On the first of these three options, there may be a significant number of statutory provisions whose legal effect has been altered by the principle of legality in a way that the meaning thesis cannot account for. Even on the second of these three options, there are statutes of contemporary importance that pre-date the principle of legality. ${ }^{91}$ By contrast, on the third option, the principle of legality may not represent a counter-example to the meaning thesis of the sort discussed in Section 4.

\section{Conclusion}

I have argued that the High Court accepts the meaning thesis - that is, the claim that the ultimate aim of statutory interpretation is to ascertain the meaning of the words contained in the provision being interpreted. I have further argued that, given its scepticism about legislative intent, the High Court cannot account for relatively uncontroversial features of the practice of statutory interpretation, such as the presumption of mens rea, consistently with the meaning thesis. However, even if the Court were to abandon its scepticism about legislative intent, it would find it difficult to account for the presumption of mens rea consistently with the meaning thesis, and would be unable to account for the operation of provisions like $\mathrm{s}$ 15AA of the Acts Interpretation Act and s 32(1) of the Charter.

Nor are the arguments in favour of the meaning thesis presented in Section 2B as strong as they may first appear. One can recognise that the words contained in a provision contribute to its legal effect without regarding the two as equivalent. Similarly, even if the enactment of a statute amounts to an act of communication by the legislature, it does not follow that the statute's legal effect depends only on what is communicated. We have seen that it may also depend on other features of the legal system that are not reflected in the statute’s linguistic content.

\footnotetext{
${ }^{88}$ See, eg, Re Bolton; Ex parte Beane (1987) 162 CLR 514; Bropho v Western Australia (1990) 171 CLR 1; Coco v R (1994) 179 CLR 427.

${ }^{89}$ Potter v Minahan (1908) 7 CLR 277.

${ }^{90}$ See Dan Meagher's suggestion that the origins of the principle may be traceable back to Somerset $v$ Stewart (1772) 98 ER 499: Dan Meagher, 'The Common Law Principle of Legality in the Age of Rights' (2011) 35 Melbourne University Law Review 449, 452-3.

${ }^{91}$ See, eg, the unamended provisions in the Customs Act 1901 (Cth) and the Defence Act 1903 (Cth).
} 
Furthermore, attempts to explain away counter-examples to the meaning thesis require compromising on other attractive features of that thesis. For example, the meaning thesis promises to place principled restraints on judicial power. However, we have seen that attempts to save the meaning thesis from counter-examples involve qualifying the thesis in various ways. (This is obviously true of the concession and avoidance strategy, but we have also seen that the reading down strategy renders the meaning thesis inapplicable to s 15AA and s 32(1) themselves.) Where the meaning thesis is qualified, so is the restraint it places on judicial power. The need for these qualifications also means that the meaning thesis does not provide the clear demarcation between the judicial and legislative roles that it may initially be thought to provide. (Consider, for example, the difficulties involved in specifying what exceptions there are to the meaning thesis under the concession and avoidance strategy.) Similarly, while the meaning thesis may appear to derive support from the doctrine of parliamentary supremacy, we have seen that some strategies for saving that thesis require us to recognise significant limits on legislative power. (Consider the suggestion that s 15AA and s 32(1) should be regarded as unconstitutional if this is necessary to save the meaning thesis.)

This is not to deny that a provision's linguistic content plays an important role in its interpretation. What words are used in the provision obviously matters. Nor do I deny that there are some provisions whose legal effect is equivalent to their linguistic content. Principles of statutory interpretation, such as those contained in s 15AA and s 32(1), do not result in every provision having a legal effect that differs from its linguistic content. What I am denying is: 1) that a provision's linguistic content is the only factor that determines its legal effect, and 2) that a provision's legal effect is typically equivalent to its linguistic content.

Admittedly, more could be said on behalf of the meaning thesis. In Section 5, I considered only some of the ways in which one might try to account for the operation of provisions like s 15AA and s 32(1) consistently with that thesis. However, enough has been said to suggest that - rather than trying to find ever more baroque strategies for saving the meaning thesis - we would be well-advised to consider other ways of thinking about statutory interpretation. 
What might an alternative to the meaning thesis look like? One possibility is that a provision's legal effect depends not only on its linguistic content but also on moral considerations. Embracing this possibility might lead us in the direction of what legal philosophers call 'anti-positivism' (roughly, the view that the content of the law ultimately depends, in part, on moral considerations), and leading anti-positivists such as Dworkin and Greenberg each offer important versions of this view of statute law. ${ }^{92}$

However, there are other options. We might think that factors other than linguistic content contribute to the legal effect of statutory provisions, without regarding those other factors as consisting of moral considerations. I shall finish by briefly indicating how we might begin to develop an account of this sort.

One thing that all my examples have in common is that they involve interaction between statutory provisions and other legal norms. These other norms may be found in other statutes (as is the case with s 15AA of the Acts Interpretation Act and s 32(1) of the Charter), in the common law (as is the case with the presumption of mens rea and the principle of legality) or even in the Constitution. This should serve to remind us that statutory provisions form part of a legal system. They often interact with other laws, and the meaning thesis has only limited resources to explain that interaction. Sometimes, the interaction affects the linguistic content of the provision being interpreted, in a way that is compatible with the meaning thesis. For example, sometimes Parliament's communicative intentions really are shaped by the realisation that the provision is enacted against a backdrop that includes certain other laws. However, as the examples in Section 4 illustrate, on other occasions the interaction alters a provision's legal effect without affecting its linguistic content.

That a provision's legal effect is not only a function of its linguistic content, but also of the way in which it interacts with other legal norms, is an important feature of complex legal systems such as ours. It is also one that the meaning thesis tends to obscure rather than illuminate, even if that thesis is treated only as a generalisation.

This suggests that, in looking for an alternative to the meaning thesis, we should seek a better understanding of the systemic nature of statute law (and, perhaps, of law in general).

\footnotetext{
${ }^{92}$ Ronald Dworkin, Law's Empire (1986) ch 9; Mark Greenberg, 'The Moral Impact Theory of Law' (2014) 123 Yale Law Journal 1288.
} 
There are various ways in which we might do so. One option is to treat the correct interpretation of a provision as determined, at least in part, by how well the competing interpretations cohere with other relevant legal norms. Such a proposal appears particularly well-suited to taking seriously the interaction between a statutory provision and other legal norms. Of course, the relevant notion of coherence, and the precise role it plays in statutory interpretation, would need to be elaborated. There are also well-known objections to coherence theories of law that would need to be addressed. ${ }^{93}$ But whether we develop this proposal or pursue some other option, we need a better understanding of the way in which statutory provisions interact with other legal norms than is offered by the meaning thesis.

\footnotetext{
${ }^{93}$ See, eg, Joseph Raz, Ethics in the Public Domain: Essays in the Morality of Law and Politics (Clarendon Press, revised edition, 1994) ch 13. For a recent attempt to develop a coherence theory that overcomes these objections, see Amalia Amaya, The Tapestry of Reason: An Inquiry into the Nature of Coherence and its Role in Legal Argument (Hart Publishing, 2015).
} 